\title{
Effect of trifluoromethanesulfonic acid on the ORR activity of Pt in acid medium
}

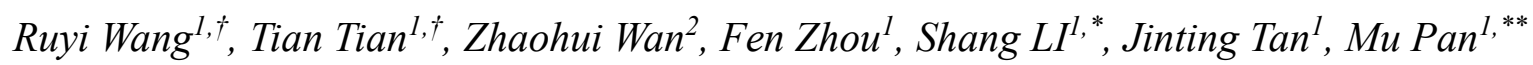 \\ ${ }^{1}$ State Key Laboratory of Advanced Technology for Materials Synthesis and Processing, Hubei \\ Provincial Key Laboratory of Fuel Cells, Wuhan University of Technology, Wuhan 430070, PR China \\ ${ }^{2}$ Wuhan WUT New Energy Co., Ltd., Wuhan 430070, PR China \\ *E-mail: lishang@whut.edu.cn \\ **E-mail: panmu@whut.edu.cn \\ ${ }^{\dagger}$ These authors contributed equally to this paper.
}

doi: $10.20964 / 2019.02 .60$

Received: 4 October 2018 / Accepted: 29 November 2018 / Published: 5 January 2019

In this paper, to study the effect of sulfonic groups on the ORR activity of Pt and exclude the effect of polytetrafluoroethylene (PTFE) backbone of Nafion, trifluoromethanesulfonic acid $\left(\mathrm{CF}_{3} \mathrm{SO}_{3} \mathrm{H}\right)$ was used to simulate the $\mathrm{SO}_{3} \mathrm{H}$-terminated side chains of Nafion. By using the $\mathrm{CO}$ displacement technique, it was predetermined that much more sulfonic groups are absorbed on the Pt surface in $50 \mathrm{mM} \mathrm{CF}_{3} \mathrm{SO}_{3} \mathrm{H}$ solution compared with that of $0 \mathrm{mM}$ and $1 \mathrm{mM}$. The influence of sulfonic groups on the oxygen reduction reaction (ORR) activity of $\mathrm{Pt}$ is analyzed by using rotating Pt disk electrode (RDE) as work electrode in $0.1 \mathrm{M} \mathrm{HClO}_{4}$ with various $\mathrm{CF}_{3} \mathrm{SO}_{3} \mathrm{H}$ contents. It is found that when the content of $\mathrm{CF}_{3} \mathrm{SO}_{3} \mathrm{H}$ is over $5 \mathrm{mM}$, the electrochemical active area of Pt decreases with increasing the content of $\mathrm{CF}_{3} \mathrm{SO}_{3} \mathrm{H}$ in solution, and the oxidation peak of Pt shifts to a higher potential. Meanwhile, the kinetic current loss of $\mathrm{Pt}$ increases apparently along with the increase of $\mathrm{CF}_{3} \mathrm{SO}_{3} \mathrm{H}$ content which is $40 \%$ for $10 \mathrm{mM}$ and $71.3 \%$ for $50 \mathrm{mM}$ at $0.9 \mathrm{~V}$, respectively. The result shows that excess sulfonic groups of Nafion adsorbed on the surface of $\mathrm{Pt}$ will greatly lower the ORR activity of $\mathrm{Pt}$.

Keywords: Sulfonic groups, kinetic current loss, Nafion, Oxygen Reduction Reaction

\section{$\underline{\text { FULL TEXT }}$}

(C) 2019 The Authors. Published by ESG (www.electrochemsci.org). This article is an open access article distributed under the terms and conditions of the Creative Commons Attribution license (http://creativecommons.org/licenses/by/4.0/). 